\title{
Związek antydemokratów z demokracją
}

\section{The Relationship of Antidemocrats to Democracy}

\author{
Tomasz Rawski*
}

\begin{abstract}
Abstrakt
Celem autora artykułu jest próba odpowiedzi na pytania: Kim są współcześni antydemokraci? Jakie są ich intencje i motywy działania? Wyzwanie stanowi też potrzeba dookreślenia antydemokratyzmu jako postawy polityczno-społecznej, a także rozstrzygnięcie dylematu, czy jest ona konsekwencją rozczarowania polityką i politykami oraz niezadowolenia społeczeństwa stanowiąc postawę kontestacji ładu politycznego, czy może użyteczną strategią polityczną prowadzącą do politycznej korzyści.
\end{abstract}

Słowa kluczowe: demokracja, demokracja liberalna, kryzys, antydemokrata, wybór

\begin{abstract}
The author of this article wants to answer the following questions: Who are modern anti-democrats? What are their intentions and motives? Challenging is also the need to clarify the idea of anti-democratism as a political and social attitude, as well as to resolve the dilemma of whether anti-democratism is a consequence of disillusionment with politics and politicians and thus an expression of public dissatisfaction and as such a basis for the attitude of contesting the political order or perhaps a useful pragmatic strategy that lead to political gain.
\end{abstract}

Keywords: democracy, liberal democracy, crisis, anti-democrat, choice

\section{Wstęp}

Demokracja to zagadnienie absorbujące umysły krytyków i ekspertów $\mathrm{z}$ wielu dziedzin. Temat poruszają prawnicy, politologowie, socjologo-

* Wydział Nauk Politycznych i Studiów Międzynarodowych Uniwersytetu Warszawskiego (tomasz-rawski@wp.pl); iD https://orcid.org/0000-0002-6486-9608 
wie, specjaliści z zakresu wiedzy o kulturze, doradcy polityków i inni. Choć problem demokracji zajmuje wiele miejsca w dysputach akademickich i codziennych polemikach, to współcześnie wydźwięk dyskusji jest bardziej pesymistyczny, przesiąknięty krytycyzmem, z którego przebija diagnoza o kryzysie, w jakim pogrąża się, lub już jest pogrążona, demokracja.

Stan ten poświadczają nie tylko badania nastrojów społecznych, deskrypcje ruchów społecznych — przyrost i radykalizacja marszów i protestów, coraz ostrzejsze formy politycznej kontestacji i oporu, lecz także widoczne zmiany na scenach politycznych. W demokracjach ugruntowanych, tych uchodzących za modelowe i wzorcowe, do głosu dochodzą ci, którzy na sztandarach bynajmniej nie niosą demokratycznych postulatów, lecz akcentują potrzebę wprowadzenia zmian w demokratycznej strukturze, a w bardziej radykalnych przekazach likwidację demokracji jako systemu politycznego. Paradoks polega na tym, że kontestatorzy nie tylko egzystują wewnątrz demokratycznego systemu politycznego, co więcej bowiem, to system ich legitymizuje, i ten system ma stać się powodem destrukcji demokracji. Antydemoraci, jak siebie określają, wybierani są na podstawie demokratycznych norm i reguł.

Celem podjętym w artykule jest próba odpowiedzi na pytania: Kim są współcześni antydemokraci? Jakie są ich intencje i motywy działania? Wyzwanie stanowi też potrzeba dookreślenia antydemokratyzmu jako postawy polityczno-społecznej, a także rozstrzygnięcie dylematu, czy jest ona konsekwencją rozczarowania polityką i politykami oraz niezadowolenia społeczeństwa, stanowiąc postawę kontestacji ładu politycznego, czy może użyteczną strategią polityczną prowadzącą do politycznej korzyści.

\section{0 jaką demokrację chodzi?}

Demokracja jest pojęciem wieloznacznym, mającym wiele desygnatów. Pisząc o demokracji, nie mamy na myśli wyłącznie systemu politycznego, którego legitymacja i ład opierają się na woli większości uprawnionej do uczestnictwa w życiu politycznym. Możemy mówić o kulturze demokratycznej, demokratycznych postawach i wartościach, demokratycznych decyzjach, standardach, o demokracji lokalnej, wreszcie — w kontekście reprezentacji - o demokratycznych stronnictwach, demokratycznych politykach itd. Rodzina wyrazów powstała wokół terminu „demokracja” pokazuje, jak pierwotnie systemowe określenie dokonuje ekspansji na liczne segmenty życia (Sartori, 1994, s. 381). Można rzec, że demokracja jako termin wyemancypowała się $\mathrm{z}$ polityczno-prawnego kontekstu i przeniknęła do wszelkich dziedzin życia. 
Ekspansji pojęcia demokracji służy także niejednoznaczny jej charakter jako systemu politycznego. Pisząc o ładzie demokratycznym, możemy odwoływać się do wielu wariantów demokracji: parlamentarna, konstytucyjna czy wcześniej ludowa bądź socjalistyczna. Warianty te pokazują, że demokracja nie jest hasłem hermetycznym, z niewzruszonym katalogiem zasad, reguł i norm, których realizacja uprawnia do stosowania określenia „demokracja” i posługiwania się nim (Dahl, 1995, s. 34).

Poszukując właściwej i modelowej definicji demokracji, nietrudno utknąć w gąszczu ujęć, perspektyw i definicji, gdyż autorzy zajmujący się tą problematyką nie są zgodni (Dahl, 1995, s. 14) co do prymarnych kategorii konstytuujących demokrację. Poszukiwań nie ułatwiają przykłady. Nawigując na mapie świata podmiotów charakteryzujących się demokratyzmem, napotkamy zbliżone trudności.

Opracowany przez Economist Intelligence Unit wskaźnik demokracji (democracy index) opisuje stan demokracji w 167 krajach świata. Do opisu i zestawienia demokratycznych standardów wykorzystano 60 kategorii i zagadnień badawczych, które w większości nawiązują do wolności, sprawiedliwości wyborów, pluralizmu i swobód obywatelskich, sprawności administracji publicznej, partycypacji politycznej i kultury politycznej. Autorzy EIU podzielili analizowane państwa na 4 kategorie: demokracje pełne (full democracies), demokracje wadliwe (flawed democracies), ustroje mieszane (hybryd regimes), ustroje autorytarne (authoritarian regimes).

Patrząc na ranking za rok 2019, w którym modelową demokracją jest demokracja norweska, nota bene monarchia konstytucyjna, a 167. miejsce zajmuje Korea Północna, założyć można na podstawie rozumienia negatywnego, że o demokratyczności orzekać będzie podobieństwo do demokratycznych wzorów z Norwegii, a o niedemokratycznym charakterze świadczy pokrewieństwo z Koreą Północną.

To duże uproszczenie, będące badawczym nadużyciem, dlatego potraktujemy je jako metaforę, niezwykle pouczającą. Takie skrajne zestawienia wskazują na analityczną pułapkę. Zarówno Norwegia, jak i Korea Północna określają siebie jako demokracje - co więcej, pełna nazwa azjatyckiego państwa to Koreańska Republika Ludowo-Demokratyczna. Jednakże komparatystyka obydwu podmiotów pokazuje, że demokracją może być tylko jeden z nich.

Tego rodzaju teoretyczne kontrasty wskazują na złożoność pojęcia demokracji. Ta bowiem ulega ciągłej redefinicji i neosemantyzacji. $Z$ jednej strony jest kategorią ustrojową, wyznaczającą granice politycznego ładu, z drugiej zaś - desygnatem zachowań, kultury i postaw, jak również retoryczną argumentacją, której celem jest oddziaływanie na umysły (Kuehnelt-Leddihn, 2008, s. 20) tych, którzy w obrębie demokracji funkcjonują, czyli obywateli 


\section{Demokracja liberalna — wzór demokracji}

Specjaliści zrzeszeni w EIU odsyłają do modelowego wariantu - demokracji liberalnej. Ta jest ładem obecnym w państwach wchodzących w skład demokracji pełnych - 24 podmioty. Demokracja liberalna, opisana jako modelowy typ, to zdaniem Francisa Fukuyamy punkt krańcowy — polityczny wzór, który ludzkość osiągnęła, a do którego reżimy niedemokratyczne powinny dążyć (Fukuyama, 2015). Szczególnym wyróżnikiem demokracji liberalnej są instytucje powołane po to, aby stać na straży praw i wolności jednostki, zapisanych w aktach prawa międzynarodowego jak Karta Praw Podstawowych czy Powszechna Deklaracja Praw Człowieka.

Demokracja liberalna jest tym ustrojem, który prowadzi do zwiększenia zakresu praw i wolności jednostki oraz budowy infrastruktury instytucjonalnej, która ma strzec tychże praw. Celem demokracji liberalnej, jak zaznaczają badacze, jest poszerzanie sfery wolności obywateli — poprawa poziomu życia, zakresu swobód (Lakoff, 1996, s. 47). To dlatego demokracje ewoluują, zmieniają się — przykładem tego może być zwrot w kierunku akceptacji dla małżeństw jednopłciowych. Jak zauważa John Keane w książce The Life and Death of Democracy, znaczenie pojęcia demokracji zmienia się w czasie. Demokracja ewoluując, absorbuje nowe wartości, zużyte bądź zdezaktualizowane zostają odrzucone (Keane, 2009). Przykładem tego może być zwrot demokratycznej polityki w kierunku wartości związanych $\mathrm{z}$ tożsamością jednost$\mathrm{ki}$, jej prawem do samoekspresji. Włączenie wartości związanych z prawem do płciowej ekspresji jednostki nastąpiło w Kanadzie podczas uchwalenia Bill C-16, czyli ustawy regulującej wolność samoekspresji i wyrażania swojej tożsamości płciowej. Więcej, C-16 wprowadzała sankcje karne - np. kary pozbawienia wolności dla osób posługujących się zaimkiem on/ona w stosunku do osób posiadających odmienną samoekspresję płciową. Dyskusja w Kanadzie nad C-16 orbitowała wokół istoty demokracji. Zwolennicy ustawy podnosili argument o wynikającym z demokratycznego ładu prawie do samoekspresji, przeciwnicy C-16 także powoływali się na demokrację, podnosząc, że wprowadzane prawo jest cenzurą dla wolności słowa - Jordan Peterson określił C-16 prawem, które wprowadza mowę wymuszona (Rojewski, 2018). Wróćmy do definicji demokracji. Eksperci zrzeszeni w Freedom House podkreślają, że istotne dla funkcjonowania i trwania demokracji liberalnej są wolne wybory, poszanowanie praw jednostki (w tym prawa mniejszości), a także respektowanie rządów prawa.

Fukuyama dokonując „apoteozy” demokracji liberalnej, zainspirował liczne podmioty polityczne i organizacyjne do propagowania tej formy politycznego ładu. Idea zawarta w artykule-eseju The End of Hisory? opublikowanym w 1989 roku w dwumiesięczniku "The National Interest" stała się wytyczną dla apolo- 
getów liberalnego ładu (Fukuyama, 1989, s. 5). Niespełna 30 lat po wygłoszeniu poglądu o końcu historii Fukuyama koryguje swoje poglądy, dostrzegając spadek zaufania do rządów i politycznych elit realizujących liberalny ład. W opracowaniu Ład polityczny i polityczny regres apeluje o konieczność reformowania liberalnych instytucji, które obarcza odpowiedzialnością za spadek efektywności liberalnego projektu (Fukuyama, 2015).

\section{Krytyka liberalnego projektu}

Krytyka demokracji liberalnej, tak dosadna i przybierająca na sile, w państwach grupy full democracies orbituje wokół poziomu życia, nieefektywności instytucji państwowych, zawodu wywołanego postawą polityków czy braku klarownego alternatywnego rozwiązania dla liberalnego porządku (Gwiazdowski, 2016, s. 19). Choć, podążając za modelem democracy index, państwa o ugruntowanej demokracji jak Norwegia, Niemcy, Kanada, Szwecja, Wielka Brytania uzyskują wysokie noty w rankingach i raportach dotyczących poziomu demokracji, to jednak w nich najdonośniej rozbrzmiewają głosy krytyczne względem tego ładu.

Pankrai Mishra w swoim Age of Anger stawia diagnozę dotyczącą źródeł roczarowania ludności liberalnym ładem. Twierdzi, że społeczeństwo aprobuje określone rozwiązania tak długo, jak długo prowadzą one do równomiernego wzrostu poziomu życia — zamożności, bezpieczeństwa oraz poczucia dumy z własnego kraju i satysfakcji z życia w nim. Brak wymiernych rezultatów $\mathrm{w}$ jednym z przywołanych obszarów prowadzi do kontestowania ładu politycznego (Mishra, 2017). Wydaje się, że Mishra trafnie wskazał na obszary życia społeczno-politycznego, w których dokonywana jest ocena liberalnego porządku. Zawód ludności wywołany aferami i skandalami politycznymi, spadek jakości życia czy brak poczucia bezpieczeństwa wpływają na kwestionowanie słuszności określonych polityk (Runciman, 2019, s. 91). Ujęcie to może posłużyć jako możliwa, jedna z wielu, ścieżka wyjaśniająca zjawiska i ruchy powstałe w obrębie ugruntowanych, modelowych demokracji — jak brexit czy zainicjowany w 2018 roku we Francji Ruch Żółtych Kamizelek.

Nie tylko czynniki polityczno-ekonomiczne, wyróżnione przez Mishrę, są składowymi kontestacji liberalnego projektu. Christophe Guilluy w Twilight of the Elites zwraca uwagę na rolę, jaką odgrywają elity w impregnowaniu liberalnego porządku (Guilluy, 2019, s. 150). Na początkowym etapie projektu elity, pod którymi kryli się politycy, eksperci, naukowcy, biznes, ludzie kultury, liderzy opinii, ludzie mediów, optowały za liberalnym ładem — poświadczały swoim autorytetem zasadność tej idei. Współcześnie, na co zwraca uwagę Guilluy, 
elity przestały agitować na rzecz politycznego ładu, zamknęły się na pozostałe części społeczeństwa, czym odtworzyły opozycję: centrum - peryferie, budząc resentymenty dotyczące elit i ich uprzywilejowania (Yasha, 2019).

W Why Liberalism Failed Patric Deneen podziela tę argumentację. Twierdzi, że elity uzyskując satysfakcjonujący poziom życia w znaczeniu gospodarczym i kulturowym, zrezygnowały z odpowiedzialności za państwo, zamykając się na problemy „życia codziennego”. Diagnozę tę rozszerza Mark Bovens w Diploma Democracy, gdzie pisze o ograniczeniu demokracji do elit. Demokracja liberalna z projektu o ambicjach ogólnych stała się projektem homogenicznym, zawłaszczonym przez elity, które ukonstytuowały się w instytucjach powołanych po to, aby strzec praw i wolności obywateli. Tymczasem działalność instytucji została wypaczona i obecnie rolą ich jest umacnianie uprzywilejowanego statusu (Bovens, 2017).

Ważnym głosem w dyskusji nad kryzysem demokracji jest ten podnoszący argument o braku narzędzi, jakie współczesne demokracje mogłyby wykorzystać do realizacji swoich celów i zadań. Zwracają na to uwagę Yves Sintomer i Liliane Lopez-Rabatel w książce Sortition and Democracy: History, Tools, Theories. Twierdzą, że demokratycznym ładom politycznym brakuje realnych narzędzi, braki te natomiast substytuują narzędziami o niedemokratycznym charakterze (Sintomer, Lopez-Rabatel, 2020, s. 75). Przykładem tego może być bezradność demokratyczno-liberalnej elity Stanów Zjednoczonych wobec zachowania Donalda J. Trumpa po przegranej w wyborach prezydenckich w 2020 roku. Demokratyczno-liberalną kontrą na zarzuty Trumpa dotyczące wyborczego fałszerstwa było blokowanie polityka w mediach społecznościowych i przerywanie przez główne media (m.in. stacje NBC, MSNBC i CNBC) jego wystąpień i oświadczeń (PRESS, 2020).

Diagnozy krytyków liberalnego ładu nie kwestionują koncepcji demokracji w całości. Wskazują na wadliwe elementy konstrukcji, które sprawiają, że współcześnie coraz częściej i głośniej mówi się o kryzysie liberalnej demokracji (Karsten, Beckman, 2012, s. 34). W niniejszym tekście nie jesteśmy w stanie zaakcentować wszystkich komponentów tej diagnozy, uczulamy zaledwie na istotne elementy.

O ile analitycy nie wskazują na potrzebę wyrugowania liberalnego projektu, o tyle politycy i aktywiści podnoszą już takie głosy. Krytykę pod adresem demokracji słychać ze wszystkich storn. Wygłaszają ją zarówno polityczni debiutanci, jak i działecze, którzy znajdują się na politycznej scenie od lat. Obrońcy liberalnego ładu zasiadający w organizacjach międzynarodowych (Rada Europy, Unia Europejska, ONZ, G7 itd.) określają kontestatorów mianem antydemokratów (Bartyzel, 2002). 


\section{Portret antydemokraty}

Pojęcie antydemokraty, podobnie jak pojęcie samej demokracji jest niejednorodne, złożone, uzależnione semantycznie od licznych zmiennych. Współcześnie antydemokrata częściej jest erystyczną etykietą niżeli hasłem określającym konkretną postawę polityczną.

Lingwistyczna analiza wyrazu ,antydemokrata” wskazuje na pewną ścieżkę rozumienia. Przedrostek anty- (w polszczyźnie) oznacza przeciwdziałający, występujący przeciw, przeciwny. Na tej podstawie domniemywać można, że antydemokrata to przeciwnik demokracji, kontestator, a nawet wróg, którego celem jest obalenie tego ustroju, ładu politycznego. Na mocy negatywnego definiowania antydemokrata powinien być jednocześnie zwolennikiem odrębnego od demokracji ustroju, powinien agitować na rzecz niedemokracji — np. monarchii czy arystokracji. Co więcej, jako zadeklarowany przeciwnik nie powinien (modelowo) korzystać z aparatury ustroju, przeciw któremu występuje (Kuehnelt-Leddihn, 2008).

Polityczna praktyka pokazuje, że antydemokratyzm, czyli postawa polityczna polegająca na kwestionowaniu założeń demokracji, dominuje w warstwie deklaratywnej, a nie formalnoustrojowej. Politycy, którzy jawnie głoszą treści antydemokratyczne, podważają podstawy ładu politycznego, jednocześnie korzystają z możliwości, jakie demokracja stwarza. Wskazuje to na paradoks demokracji, który niekiedy metaforycznie i żartobliwie określany jest jako „wybór lisa na szefa kurnika". To wybór z wykorzystaniem demokratycznych mechanizmów i instrumentów, polityków i aktywistów, których polityczne ,ja” nawiązuje do demokratyzmu po to, aby istniejącego ładu polityczny nie unicestwić, ale go zreformować. Zanim jednak przejdziemy do bliższego spojrzenia na oblicza antydemokratów, wskażmy, że pośród samych antydemokratów mamy co najmniej dwie formy samookreślania. $Z$ jednej strony znajdują się wśród nich przeciwnicy demokracji, którzy demonstracyjnie akcentują swoją niedemokratyczną orientację, są np. monarchistami dążącymi do restauracji korony, z drugiej strony zaś widoczni są krytycy określonej formy demokracji, pewnego wariantu, np. demokracji socjalistycznej, ludowej, liberalnej, reprezentacyjnej, których celem jest zmiana konkretnego rodzaju demokracji.

W polskiej rzeczywistości politycznej wskazać możemy na wielu wyrazistych antydemokratów. Jednym z nich jest Janusz Korwin-Mikke, który w wieloletniej działalności politycznej powtarza diagnozę dotyczącą demokracji:

W demokracji rządzi większość, a głupich jest więcej niż mądrych ${ }^{1}$.

\footnotetext{
${ }^{1}$ https://www.youtube.com/watch?v=KLs0heb10ZA (data dostępu: 1.02.2021).
} 
Drugim wyrazistym antydemokratą jest Grzegorz Braun. W spocie wyborczym z czasów wyborów prezydenckich 2015 Braun powiedział:

Nazywam się Grzegorz Braun. Jestem niezależnym reżyserem. Nie należę do żadnej partii. Nie wierzę w demokrację, bo za jej fasadą rządzą mafie, służby i loże. Jestem monarchistą, bo cenię wolność i szanuję tradycję².

Zarówno Korwin-Mikke, jak i Braun są zdeklarowanymi monarchistami, kontestatorami i krytykami liberalnego porządku demokratycznego, których celem jednak jest takie funkcjonowanie w demokratycznym porządku, aby możliwie radykalnie go przekształcić. Mamy tu do czynienia $\mathrm{z}$ ewolucyjną formą zmian politycznych. Rewolucyjną, siłową formą zmiany ustroju politycznego są wszelkie przewroty, masowe protesty (Sartori, 1994, s. 551) itd.

\section{Antydemokrata nieliberalny}

Opozycja względem demokracji nie musi być tożsama z zakusami likwidacji porządku demokratycznego w ogóle. Często antydemokratyzm przybiera formę oporu i sprzeciwu wobec konkretnego wariantu demokracji: socjalistycznej, zachodniej czy liberalnej. Wówczas antydemokrata nie jest zagorzałym kontestatorem demokracji jako ustroju politycznego, ale występuje przeciw tym zmianom politycznym, które w jego opinii zaburzały właściwy porządek demokratyczny - np. zbyt duża koncentracja na kwestii równouprawnienia i tolerancji obecna w zachodnich demokracjach (Nowak, 2018, s. 35).

Pamiętać należy, że antydemokratyzm nie jest postawą holistyczną, tzn. nie musi nawiązywać do całości problemu - nie musi kwestionować demokracji w ogóle. Ten rys antydemokraty jest często spotykany. Jego wariant stanowi antysystemowość i występowanie przeciw elitom. Reprezentanci takiej postawy politycznej nie kwestionują całości porządku politycznego, ale podważają zasadność kilku jego elementów, jak np. rozrost biurokracji czy ograniczanie wolności gospodarczej.

Trzeba podkreślić, że często antydemokratyzm jest erystycznym zabiegiem etykietowania skierowanym w przeciwnika politycznego. Obrońcy liberalnego konsensu negatywnie określają tego, kto nie podziela w pełni ich poglądów podważa istniejący model demokracji - określają go mianem antydemokraty. Tymczasem bywa tak, że polityk określony mianem antydemokraty nie jest

\footnotetext{
${ }^{2}$ Ibidem.
} 
przeciwnikiem demokracji en bloc, ale w swojej działalności koncentruje się na recenzowaniu tych segmentów ładu politycznego, które jego zdaniem nie funkcjonują na właściwym poziomie (Reykowski, 2019).

Przykładem takiego polityka jest, w Polsce, Paweł Kukiz, który zapoczątkował ruch Kukiz'15. Celem ruchu było „oddanie Polski jej obywatelom”. Kukiz nie wypowiadał się krytycznie o demokracji w ogóle, kwestionował jej mutację w kierunku biurokratycznego molocha, gdzie obywatel skazany jest na podległość, a nie podmiotowość. Określany przez konkurentów politycznych jako antydemokrata Kukiz w istocie nim nie jest. W tekstach programowych i wyborczych kładzie nacisk na ludowładztwo, sprzeciwia się elitom i kwestionuje zasadność ulegania obcym wpływom (Paluszyński, 2016, s. 40-70). A zatem jego program $\mathrm{w}$ wielu miejscach spójny jest $\mathrm{z}$ komponentami demokracji podkreślanymi przez democracy index.

Antydemokratyzm wynikający $\mathrm{z}$ generalizacji i erystycznej etykiety często osadzony jest na gruncie demokratycznych wartości — jak poszanowanie mniejszości, prawa emigrantów itd. Prawa te niewątpliwie wchodzą w poczet wartości demokratycznych, jednak nie orzekają jednoznacznie o tym, czy mamy do czynienia z demokracją, czy nie. Jesteśmy w stanie podać wiele przykładów, gdzie prawa mniejszości są sukcesywnie wprowadzane, nie pakietowo, a swobody emigrantów są daleko ograniczone - i będą to przykłady modelowych demokracji. Antydemokratyzm wynikający z rezerwowego stosunku względem poszczególnych wartości wchodzących $\mathrm{w}$ poczet demokratycznego katalogu także obciążony jest dialektyką erystyczną. Działacze i politycy, którzy nie akceptują np. małżeństw jednopłciowych, mogą zostać uznani za wrogów demokracji — antydemokratów.

Widać tu, że antydemokratyzm może przybierać odcień sprzeciwu nie tyle wobec konstrukcji polityczno-ustrojowej, ile wobec wartości uwypuklanych w demokratycznym systemie politycznym. Przykład tego stanowi Jair Bolsonaro wybrany w 2018 roku na prezydenta Brazylii. Polityk znany z radykalnego kursu względem emigrantów to zwolennik dostępu do broni palnej, a także zdeklarowany przeciwnik mniejszości seksualnych. Stosunek do mniejszości seksualnych często traktowany jest jako probierz demokratycznych standardów, które tożsame powinny być z akceptacją dla odmienności, tolerancją, szacunkiem wobec różnorodności (Antoszewski, 2018, s. 57). Brazylijscy aktywiści ruchu LGBT+ jednoznacznie określają Bolsonaro mianem antydemokraty. Bolsonaro zapowiada delegalizację małżeństw jednopłciowych, jednak ku temu potrzebuje stosownej większości politycznej, której nie ma. Dlatego konsekwentnie realizuje ofensywę względem mniejszości seksualnych, reglamentując dostęp do niektórych elementów opieki medycznej, wprowadzając restrykcje dotyczące podejmowania pracy osoby LGBT $+\mathrm{w}$ oświacie itd. Z jednej strony decyzje Bolsonaro są demokratyczne - mają demokratyczną legitymację, ugruntowaną $\mathrm{w}$ procedurze wolnych, powszechnych wyborów. Z drugiej strony nie są spój- 
ne z katalogiem demokratycznych wartości liberalnych. Stoją do nich w ostrej sprzeczności (Sartori, 1994, s. 449).

Antydemokratyczny nastrój w Brazylii potęgują wypowiedzi prezydenta Bolsonaro, który krytycznie wypowiada się o demokratach, zestawiając ich z bojówkami lewicowymi, jak również dosadnie krytykując wszelkie mniejszości np. słowami, że:

sam nie zaakceptowałby swojego syna, gdyby ten okazał się homoseksualistą ${ }^{3}$.

oraz że:

lesbijki mu nie przeszkadzają tak długo, jak są atrakcyjne ${ }^{4}$.

To nieliczne fragmenty wypowiedzi skierowane przeciw mniejszościom. Bolsonaro stanowi przykład antydemokraty w ujęciu aksjologicznym. Uznaje procedury polityczno-ustrojowe, dzięki którym uzyskał polityczną pozycję, jednakże nie akceptuje katalogu wartości, reguł i praw, które ukonstytuowały się w toku demokratycznych przemian. Co więcej, wykorzystując demokratyczny mandat, zamierza je zreformować — demokratycznie zamierza zmieniać demokrację.

\section{Nie antydemokracja, ale inna demokracja}

Krytyka demokracji liberalnej — pozorny antydemokratyzm — jest często przyczynkiem do konstytuowania alternatywnego względem liberalnego ładu projektu (Deneen, 2018). Politycy czy stronnictwa polityczne nader często korzystają ze sposobności do punktowania błędów i dysfunkcji demokracji liberalnej tak, aby niejako w krytyce zawrzeć propozycję nowego ładu, oryginalnego wariantu demokracji liberalnej.

Jednym z głównych aktorów politycznych, krytykujących założenia demokracji liberalnej, jest premier Węgier Viktor Orban. Polityk znany ze sceptycyzmu względem instytucji międzynarodowych upowszechniających założenia i komponenty liberalnego projektu nie raz akcentował swój sprzeciw wobec tych propozycji. Orban jest tym, który pokazuje, że w kontrze do demokracji liberalnej nie zawsze krytyczny punkt ciężkości znajduje się w miejscu demokracji.

\footnotetext{
${ }^{3}$ https://www.polityka.pl/tygodnikpolityka/swiat/1776922,1,w-brazylii-geje-i-lesbijki-ze -strachem-wchodza-w-nowy-rok.read.

${ }^{4}$ Ibidem.
} 
Dla premiera Węgier winę za dysfunkcję demokracji liberalnej ponosi liberalizm, który jako doktryna polityczna uległ licznym wypaczeniom, pozbawiając się treści w postaci wolności jednostki i ochrony jej praw. Dla Orbana to liberalizm i jego wypaczenia spowodowały kryzys demokracji, a brak odejścia od założeń doktryny wolnościowej doprowadzi do pogłębiania się tego kryzysu (Deneen, 2018).

Podczas obchodów 100. rocznicy urodzin Jana Pawła II Orban powiedział w Rzymie:

Spójrzcie na Europejską Partię Ludową. Należymy do EPL. Co się dzieje w EPL? Nasze członkostwo w niej jest zawieszone, ponieważ jesteśmy „czarną owcą" Unii, więc mogę powiedzieć to, co myślę. EPL chciałaby być częścią struktury władzy Unii Europejskiej za wszelką cenę. Jeśli ceną za to ma być oddanie pewnych wartości i kompromis $\mathrm{z}$ lewą stroną, zrobi to. I tak właśnie tracimy naszą tożsamość, krok po kroku. Najpierw stajemy się centrystami, potem liberałami, a w końcu lewakami. Ten proces dzieje się!

Krytykując unijne struktury, gdzie zdaniem Orbana znajduje się centrum liberalnego ładu, polityk nie tyle stawia diagnozę polityczną, ile podaje antidotum. Będąc antydemokratą w znaczeniu opozycji względem demokracji liberalnej, Orban tworzy alternatywny wariant dla niekorzystnego jego zdaniem porządku politycznego. Wariantem tym dla demokracji liberalnej ma być demokracja chrześcijańska. Zarys programowy tego projektu Orban przedstawił w 2018 roku podczas XXIX sesji Wolnego Uniwersytetu Letniego i Obozu Młodzieży w Băile Tuşnad.

W liberalnej Europie bycie Europejczykiem w rzeczywistości niczego już nie oznacza, nie wyznacza już żadnego kierunku, pozostaje tylko forma pozbawiona treści. Na dodatek, Szanowni Państwo, liberalna demokracja przepoczwarzyła się w liberalną nie-demokrację. Na Zachodzie sytuacja wygląda tak, że jest liberalizm, ale demokracji nie $\mathrm{ma}^{6}$.

Orban wprawdzie nie mówi o antydemokracji, ale o nie-demokracji, pozostaje w obszarze opozycji względem demokracji, wypaczenia tej formy politycznego ładu.

\footnotetext{
${ }^{5}$ https://wpolityce.pl/polityka/486046-orban-o-chadecji-najpierw-stajemy-sie-centrysta$\mathrm{mi}$

${ }^{6} \mathrm{https} / / /$ wpolityce.pl/swiat/407106-tylko-u-nas-glosne-przemowienie-viktora-orbanacaly-tekst.
} 
Liberalna koncepcja wolności opinii rozwinęła się już do tego stopnia, że różnorodność poglądów uważa się za ważną tylko do momentu, w którym ze zdziwieniem stwierdza się, że istnieją odmienne poglądy. Liberalna wolność prasy przypomina nam starą, sowiecką anegdotę: jak by nie składać części z sowieckiej fabryki rowerów, to na koniec i tak zawsze wychodzi z tego broń maszynowa. Jakkolwiek by nie składać liberalnej wolności prasy, na koniec i tak zawsze wychodzi z tego cenzura?

Polityk uwypukla wady demokracji liberalnej, które wskazują na jej związek z systemem elit i grup uprzywilejowanych. Co więcej, Orban kwestionuje demokrację liberalną za strukturalną hipokryzję - w projekcie zabiega się bowiem o poszanowanie odmienności i alternatywnych opinii, ale tylko wtedy, kiedy te nie dotyczą demokracji liberalnej. Orban uważa, że demokracja liberalna szanuje wszelkie odmienności poza odmienną wizją demokracji (Runciman, 2019, s. 102). Polityk nie proponuje likwidacji demokracji jako takiej. Postuluje wyrugowanie liberalnego członu i zastąpienie go członem, który utożsamia i oddaje wartości podzielane przez krytyków i opozycjonistów demokracji liberalnej alternatywną możliwością dla niej ma być demokracja chrześcijańska:

Dlatego też elitę liberalną można zastąpić elitą chrześcijańsko-demokratyczną. Ale w Europie w kwestii związku chrześcijaństwa z polityką panuje chaos i wiele nieporozumień.

W chrześcijańskiej demokracji nie chodzi o to, by bronić prawd wiary, w tym przypadku prawd wiary chrześcijańskiej. W kwestiach wiecznego potępienia czy zbawienia ani państwa, ani rządy nie mają żadnych kompetencji.

Polityka chrześcijańsko-demokratyczna oznacza ochronę form życia, które wyrastają z kultury chrześcijańskiej; a więc nie prawd wiary, ale wynikających z nich form życia. Należą do nich godność człowieka, rodzina, również naród.

Chrześcijaństwo dąży do uniwersalizmu nie poprzez likwidację narodów, jak to czynią internacjonaliści, lecz poprzez zachowanie narodów. Takie są nasze wspólnoty wiary, musimy ich bronić i wzmacniać je. Oto zadanie dla chrześcijańskiej demokracji ${ }^{8}$.

Chrześcijańska demokracja stanowi konkurencję dla demokracji liberalnej przede wszystkim w obszarze aksjologii i komponentów politycznych:

\footnotetext{
7 Ibidem.

8 Ibidem.
} 
Powiedzmy to z pełnym spokojem: chrześcijańska demokracja nie jest liberalna. Liberalna demokracja jest liberalna, chrześcijańska demokracja z definicji liberalna nie jest. Można powiedzieć, że jest ona nieliberalna.

Możemy to pokazać konkretnie na przykładzie trzech ważnych spraw. Demokracja liberalna popiera ideologię multikulturalizmu, demokracja chrześcijańska zaś daje pierwszeństwo kulturze chrześcijańskiej, a to jest pogląd nieliberalny.

Demokracja liberalna jest stronniczką imigracji, demokracja chrześcijańska zaś jest temu przeciwna, to również myśl na wskroś nieliberalna. Wreszcie demokracja liberalna jest stronniczką różnych wariacji modelu rodziny, podczas gdy demokracja chrześcijańska stoi na fundamencie chrześcijańskiego modelu rodziny, co też jest poglądem nieliberalnym?

Orban krytykując demokrację liberalną, proponuje zamianę członu „liberalna” na człon „chrześcijańska”. Optuje za zmianą wariantu demokracji, nie agitując na rzecz destrukcji demokracji jako takiej.

W demokracji traktowanej jako system polityczny — sposób wyłaniania władz, model reprezentacji i partycypacji pozostają niezmienne. Reformie ulega treść wypełniająca te założenia. Liberalne postulaty, jak akceptacja multikulturalizmu, nowy model rodziny czy wreszcie kwestie związane $\mathrm{z}$ ponadnarodowym rządem, zastąpione mają zostać poglądami ukonstytuowanymi na gruncie kultury chrześcijańskiej. Demokracja jako taka pozostaje formą, wypełni ją inna treść.

Projekt Orbana łączy się z przywoływaną diagnozą Mishry dotyczącą efektywności projektu liberalnego. Ten akceptowany jest tak długo, jak długo społeczeństwo ma zapewnione potrzeby bezpieczeństwa, przynależności i potrzeby ekonomiczne. Zakłócenia w jednym $\mathrm{z}$ tych segmentów prowadzą do kwestionowania ładu politycznego w obszarze nie tyle konstrukcji ustrojowej, ile właśnie wartości. Dodać należy, że instalacja nieliberalnego ładu na Węgrzech rozpoczęła się przy powrocie Orbana do władzy w 2010 roku, a tło tego politycznego wyboru stanowiła poważna zapaść węgierskiej gospodarki i zwątpienie tamtejszej ludności w powodzenie jakichkolwiek reform poprawiających jakość ich życia.

9 Ibidem. 


\section{Antydemokratyzm jako strategia autoprezentacji}

Analizując przykłady Bolsonaro, Kukiza, Korwin-Mikkego i Orbana, trudno nie stwierdzić, że antydemokratyzm nie jest jednoznaczną kategorią. Wyrazicielami pojęcia antydemokraty mogą być różni gracze, prezentujący skrajnie odmienne poglądy na kwestie związane z ładem społeczno-politycznym. Prócz istnienia krystalicznych antydemokratyów - przeciwników demokracji (Kelsen, 1936, s. 23) jako takiej mamy do czynienia z graczami kwestionującymi jakąś cześć ustroju politycznego i kultury politycznej, w której funkcjonują. Zróżnicowanie to pozwala na potraktowanie antydemokraty jako strategii politycznej, maski nakładanej przez polityka po to, aby zagospodarować niezadowoloną cześć elektoratu. Dodać należy, że często jest to strategia polegająca na ogólnym i powierzchownym kwestionowaniu sytuacji politycznej, krytykowaniu nie pojedynczych elementów systemu politycznego, ale jego całości.

Strategia antydemokracji może być zarówno elementem kreowania wizerun$\mathrm{ku}$, jak i destrukcyjnym oddziaływaniem na wizerunek przeciwnika — oponenta demokracji. Wspomnieliśmy o „łatce” antydemokraty, która może być destrukcyjną formą koordynowania wszelkich przejawów oporu względem demokracji. Zarzut czy posądzenie stronnictw krytycznych o tendencje antydemokratyczne może być tym, co niweluje ich potencjał i siłę na scenie politycznej — jest tym, co nakłada na nie piętno podmiotu, który jest nieprzychylny całemu systemowi.

\section{Antydemokratyzm jako dywidenda gniewu}

W rozważaniach na temat antydemokracji wskazać należy na znaczenie niezadowolenia, rozczarowania i frustracji po stronie obywateli. Ujawniliśmy, że czynniki ekonomiczne, bezpieczeństwa czy prestiżu wpływają na aprobatę i akceptację istniejącego ładu. Ich zachwianie potęguje niezadowolenie, wyzwalając w określonej proporcji, ruchy odśrodkowe, które zagospodarowane mogą zostać przez antydemokratów.

Peter Sloterdijk w eseju Gniew i czas wprowadza pojęcie banku gniewu, którym nawiązuje do instytucji i organizacji żywotnie zainteresowanych pomnażaniem gniewu społeczeństwa i upowszechnianiem go. Sloterdijk pisze o ,świeckich duchownych gniewu”, którymi są politycy, ideologowie, autorytety umiejętnie wzbudzające gniew pośród ludzi tak, aby następnie instrumentalnie wykorzystać go do realizacji politycznych celów (Sloterdijk, 2011, s. 35, 70, 75). Bank gniewu jest niczym innym jak kumulowaniem negatywnych emocji po- 
wstałych wokół określonej sprawy. Deponowane są tam liberalne i demokratyczne problemy, kwestie, wątpliwości, które mają potencjał wywoływania afektów pośród odbiorców.

Antydemokracja może zostać potraktowana jako bank gniewu, o którym pisze Sloterdijk. Konstrukcja ustrojowo-ideologiczna antydemokracji sprawia, że pojęcie to generuje skrajnie odmienne skojarzenia, odwołuje się do wielu czynników społecznych, angażując i przykuwając uwagę licznych graczy. Przez to antydemokracja może zrzeszać zarówno skrajnie gniewne odczucia, jak i zwolenników demokracji owładniętych strachem przed aktywnością przeciwników demokracji.

Składowe antydemokratycznych przekazów to kryzysy, nieefektywność instytucji, buta i arogancja polityków, poczucie zagrożenia, a zatem wszystko to, co ma potencjał budzenia gniewu. Politycy, a szczególnie ci z wizerunkiem antydemokraty, zainteresowani są odkładaniem w banku gniewu społecznych rozczarowań i frustracji po to, aby następnie wypłacić dywidendę tych oszczędności, która metaforycznie określa polityczny sukces.

\section{Zakończenie}

Pojęcie Sloterdijka „bank gniewu” pokazuje, że paradoks demokratycznego związku demokracji z antydemokratami, budzący początkowo skojarzenia znieefektywnością systemu czy dziurami systemu demokratycznego, który toleruje i dopuszcza aktywistów jawnie łamiących jego podstawy, wcale nie musi być jedynym wyjaśnieniem zjawiska. Wewnątrz samej demokracji powstają rozmaite warianty i mutacje, które akcentują potrzebę zmian. Tymczasem, na przykładzie liberalnego ładu i powstających wokół niego kontrowersji i gniewu widać, że projekt ten został uwikłany w konflikt prowokujący konieczność wyboru: zmiana i reforma czy obrona istniejącego porządku.

Nawiązując do pojęcia banku gniewu, należy zastanowić się, czy wpłat do tej kasy niechęci, animozji i frustracji dokonują wyłącznie ci, których określa się mianem antydemokratów. Prawdopodobnie nie, mamy tu bowiem do czynienia z konstrukcją koegzystencji i potrzebą posiadania wroga. Dla demokratów fakt istnienia kogoś, kogo określić można mianem antydemokratów, jest sposobem na realizację reform i integrację swoich zwolenników, dla antydemokratów zaś istnienie postępowych demokratów stanowi sposób na poszerzanie wpływów i źródłem politycznej energii.

Friedrich August von Hayek w Drodze do zniewolenia pisał, że państwo poszerzając swoje wpływy, zmienia charakter ludzi, zmienia konstrukcję psychologiczną jednostki, prowadząc w efekcie do „rozpieszczającego uzależnienia” 
(Hayek, 1996). Spotykamy się tu z cytowanymi na początku tekstu krytycznymi uwagami na temat demokracji, które oddać można opozycją: demokratyczna grupa beneficjentów kontra antydemokratyczna grupa nieuczestnicząca. To zupełnie tak, jakby beneficjentami demokracji byli tylko ci, którzy podzielają w pełni, całościowo, jej programowe założenia. Tak, jakby nie było demokracji dla krytyków demokracji. Być może frustracja antydemokratów, ich siła i determinacja pochodzą właśnie z tej relacji.

Wskazać należy na proporcję w radykalizacji zachowań i postaw. Zaprezentowany wywód może sugerować, że radykalne postawy są domeną tych spod znaku antydemokracji. Pamiętać należy, że radykalni i zdecydowani w zwalczaniu kontestatorów i krytyków ładu są także demokraci, którzy korzystając $\mathrm{z}$ uprzywilejowanej pozycji, angażują w te działania media, organizacje społeczne, NGO-sy i elity.

Działania skierowane w antydemokratów mają podwójny charakter. Z jednej strony są stygmatyzacją, wskazaniem wrogich sił zagrażających demokratycznemu porządkowi, z drugiej strony towarzyszy im przyspieszanie i intensyfikacja zmiany demokracji liberalnej: według reguły „więcej demokracji w demokracji”. Przykładem takich działań może być The 1619 Project 10 przygotowany przez „New York Times”. Celem przedsięwzięcia jest kontrnarracja wobec legendy statku Mayflower, czyli mitu założycielskiego Stanów Zjednoczonych. Autorzy z NYT przyjmują, że mitem założycielskim jest związek Stanów Zjednoczonych z niewolnictwem. Przykładem radykalnego wykluczenia antydemokratów z życia społecznego może być akcja zapoczątkowana przez NYT nawołująca do stygmatyzacji i usuwania spośród znajomych osób, które nie walczą z rasizmem, a nawet są ambiwalentne wobec tego problemu ${ }^{11}$. Narodowe Centrum Kultury Afroamerykańskiej Smithsonian organizuje antyrasistowskie warsztaty, których celem jest „dotarcie do prawdy o białej supremacji” ${ }^{2}$. W broszurach warsztatów czytamy, że racją demokratycznej polityki jest radykalna walka z wszelkimi przejawami rasizmu, a także: przełamanie białej supremacji.

Przywołane przykłady, uproszczone i punktowe, wskazują na tendencję. Jest nią radykalizacja nastrojów i silna polaryzacja w walce o możliwość decydowania o tym, jak będzie wyglądała demokracja, w którym kierunku będzie ewoluowała. Jak widać, radykalizacja postaw i działań jest domeną nie tylko tych,

${ }^{10}$ Więcej o projekcie przeczytać można na oficjalnej stronie. NYT.The 1619 Project. Pobrano z: https://www.nytimes.com/interactive/2019/08/14/magazine/1619-america-slavery. html (data dostępu: 1.02.2021).

11 Więcej o przedsięwzięciu można przeczytać w oficjalnym komunikacie redakcji NYT.: I Don't Need 'Love' Texts From My White Friends. I Need Them to Fight Anti-blackness. NYT. Pobrano z: https://www.nytimes.com/2020/06/05/opinion/whites-anti-blackness -protests.html (data dostępu: 1.02.2021).

12 Więcej o projekcie przeczytać można na oficjalnej stronie National Museum of African American History and Culture Pobrano z: Talking about Race: https:/nmaahc.si.edu/ learn/talking-about-race (data dostępu: 1.02.2021). 
których określa się mianem antydemokratów, ale także tych, którzy są zwolennikami i obrońcami demokratycznego porządku. Taka interpretacja może sugerować dotąd niewskazane w tekście wyjaśnienie. Antydemokrata nie jest maską polityczną ani strategią polityczną, ale efektem silnej polaryzacji sceny politycznej — przesunięcia się osi podziału politycznego.

\section{Bibliografia}

The 1619 Project. NYT. Pobrano z: https://www.nytimes.com/interactive/2019/08/14/ magazine/1619-america-slavery.html (data dostępu: 1.02.2021). Antoszewski, A. (2018). Demokracja nieliberalna jako projekt polityczny. W: K.A. Wojtaszczyk, P. Stawarz, J. Wiśniewska-Grzelak (red.), Zmierzch demokracji liberalnej (s. 51-68). Warszawa: ASPRA-JR.

Bartyzel, J. (2002). Demokracja. Radom: PWE

Bovens, M. (2017). Diploma Democracy: The Rise of Political Meritocracy. Oxford: University Press

Dahl, R. (1995). Demokracja i jej krytycy. Przeł. S. Amsterdamski. Kraków: Znak.

Deneen, P. (2018). Why Liberalism Failed. Yale: University Press.

EUI - democracy index. Pobrano z: https://www.eiu.com/topic/democracy-index (data dostępu: 1.05.2021).

Freedom House | Championing Democracy. Pobrano z: https://freedomhouse.org (data dostępu: 1.02.2021).

Fukuyama, F. (2015). Ład polityczny i polityczny regres. Od rewolucji przemystowej do globalizacji demokracji. Przeł. J. Pyka. Poznań: Rebis.

Fukuyama, F. (1989). The End of Hisory?The National Interest, 16, s. 3-18.

Guilluy, Ch. (2019). Twilight of the Elites: Prosperity, the Periphery, and the Future of France. Yale: University Press.

Gwiazdowski, R. (2016). Równość i (nie)sprawiedliwość. Warszawa: Fijor.

Hayek, F. A. von (1996). Droga do zniewolenia. Przeł. K. Gurba [et al.] Kraków: Arcana.

Karsten, F., Beckman K. (2012). Mity demokracji. Przeł. J.M. Fijor. Warszawa: Fijor. Keane, J. (2009). The Life and Death of Democracy. New York: Simon\&Schuster

Kelsen, H. (1936). O istocie $i$ wartości demokracji. Autoryz. przekł. F. Turynowa. Warszawa: Księgarnia Powszechna.

Kuehnelt-Leddihn, E. von. (2008). Demokracja - opium dla ludu. Przeł. M. Gawlik. Wrocław: Wydawnictwo Thesaurus.

Lakoff, S. (1996). Democracy: History, Theory, Practice. Boulder: Westview Press. Mazzini, M. (2019). W Brazylii geje i lesbijki ze strachem wchodzą w nowy rok. Polityka, 1.01.2019, Pobrano z: https://www.polityka.pl/tygodnikpolityka/ swiat/1776922,1,w-brazylii-geje-i-lesbijki-ze-strachem-wchodza-w-nowy-rok. read (data dostępu: 1.02.2021). 
Mishra, P. (2017). The Age of Anger: A History of the Present. New York: Farrar, Straus, and Giroux.

Nowak, L. (2018). Kruche podstawy demokracji liberalnej. W: K.A. Wojtaszczyk, P. Stawarz, J. Wiśniewska-Grzelak (red.), Zmierzch demokracji liberalnej (s. 31-50). Warszawa: ASPRA-JR.

Orban podczas 100. rocznicy urodzin Jana Pawła II. Wpolityce.pl. Pobrano z: https:// wpolityce.pl/polityka/486046-orban-o-chadecji-najpierw-stajemy-sie-centrystami (data dostępu: 1.02.2021).

Paluszyński, T. (2016). Mankamenty demokracji. Poznań: Rys.

Rojewski, J. (2018). Kontrowersyjna „,filozofia Jordana Petersona”. Polityka. Pobrano z: https://www.polityka.pl/tygodnikpolityka/ludzieistyle/1769326,1,kontrowersy jna-filozofia-jordana-petersona.read (data dostępu: 1.02.2021).

Reykowski, J. (2019). Rozczarowanie demokracja. Warszawa: Smak Słowa.

Runciman, D. (2019). Jak kończy się demokracja. Przeł. S. Żuchowski. Warszawa: Fundacja Kultura Liberalna.

Sartori, G. (1994). Teoria demokracji. Przeł. P. Amsterdamski, D. Grinberg. Warszawa: PWN

Sintomer, Y., Lopez-Rabatel, L. (2020). Sortition and Democracy: History, Tools, Theories. Exeter: Imprint Academic.

Sloterdijk, P. (2011). Gniew i czas. Esej polityczno-psychologiczny. Przeł. A. Żychliński. Warszawa: Scholar.

Stacje NBC przerwały wystąpienie Trumpa ogłaszającego zwycięstwo, PRESS. Pobrano z: https://www.press.pl/tresc/63831,stacje-nbc-przerwaly-wystapienietrumpa-oglaszajacego-zwyciestwo (data dostępu: 4.03.2021).

Wykład Viktora Orbána n XXIX Wolnym Uniwersytecie Letnim i obozie młodzieżowym „Tusványos Tusnádfürdő (Băil Tuşnad). Wpolityce.pl. Pobrano z: https://wpolityce.pl/swiat/407106-tylko-u-nas-glosne-przemowienie-viktora-orbana-caly-tekst (data dostępu: 1.02.2021).

Yasha, M. (2019). Lud kontra demokracja. Przeł. K. Gucio. Warszawa: Fundacja Kultura Liberalna. 